\title{
Parerga to the Stadiasmus Patarensis (17): A Correction to the Course of the Road between Xanthos and Neisa
}

\author{
Fatih ONUR*
}

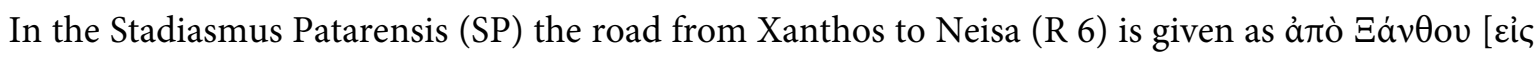

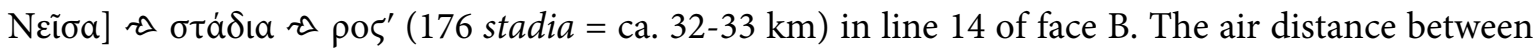
two cities is $28-29 \mathrm{~km}$, meaning that, if the distance of 176 stadia on the block is correct, the road should lead as direct as possible to accord with the SP. But, our research of 2009-2010 showed that this road led through Çavdır, Çayköy, Üzümlü (Margaz), İslamlar (Bodamya), near Lapaz, the Alacaışık Pass by Köybaşı/Gölbaşı, passing in western vicinity of İkizce, Akarkuyu, Lengüme (Çamlıova) and Sütleğen (see below Fig. 1), ${ }^{1}$ covering a distance of no less than ca. $40 \mathrm{~km}$ (ca. 215/6 stadia).

This is a much longer distance than that recorded by the SP, Şahin estimated this difference as 10,5 $\mathrm{km}^{2}{ }^{2}$ as shown in the map below (Fig. 1). These extra lengths measured to Xanthos, both from Sütleğen and Lengüme, were explained as due to the possible different courses of the modern road on the mountainous sections, which extended the length of these routes. The milestone from Lengüme, which probably dates from no earlier than the Severan Period and is today lost, also played an important role on this consideration, inasmuch as it was erected on the south-western point of Lengüme, and records $16 \mathrm{mp}$ (= ca. $23 / 24 \mathrm{~km}$ ) from its destination, which was repeatedly and confidently asserted to be Xanthos. ${ }^{3}$ This distance, with an extra distance of 2-3 km, seems to correspond roughly to the actual length of ca. $25-26 \mathrm{~km}$ between the find spot of this milestone and Xanthos, following a route through Köybaşı. In any case, the length between Xanthos and Neisa in the SP and the length of the course proposed by Şahin and later adopted by Takmer and Oktan, which mostly corresponds with the modern road between Kınık and Sütleğen, diverge from each other. In

\footnotetext{
* Assoc. Prof. Fatih Onur, Akdeniz University, Faculty of Letters, Dept. of Ancient Languages and Cultures, Campus 07058 Antalya (fatihonur@akdeniz.edu.tr).

This contribution results from the "Stadiasmus Patarensis" field surveys directed by the late Prof. Dr. Sencer Şahin until 2014 and thereafter by Prof. Dr. N. Eda Akyürek Şahin with the permission from the Turkish Ministry of Culture and Tourism. These field surveys have been supported by the Akdeniz University Scientific Research Projects Coordination Unit (project no.: SBA-2015-937, conducted by Prof. Dr. N. Eda Akyürek Şahin) from 2015 onwards. In behalf of our survey team, I thank for the support provided by Koç University Suna \& İnan Kıraç Research Center on Mediterranean Civilizations. I am deeply grateful to our research assistants Hüseyin Uzunoğlu and Fatma Avcu, who walked, tracked with GPS and photographed the roads, and also recorded the other relevant data in the field. They have an important part in the completion of this paper. I thank Terrance M. P. Duggan for his black-pen sketch drawings of the relevant areas (see Fig. 29-Fig. 30) and for his remarkable observations, and Ceren Demirton, who also walked with us, took photographs and shared her ideas on the geography.

${ }^{1}$ Takmer - Oktan 2013, 63-65 and the map in 93; Şahin 2014, 146-152 and the map of central Lycia.

${ }^{2}$ Şahin 2014, 147.

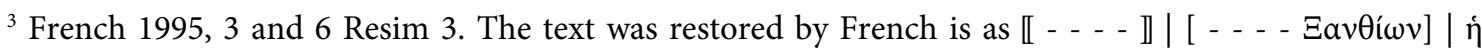

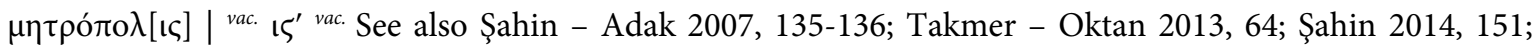
French 2014, 60 no. 25.
} 
such a situation, one may think that either the number (or perhaps the destination?) of R6 in the SP is incorrect (or perhaps the surveyors of the SP measured the distance incorrectly or it was recorded incorrectly on the SP).

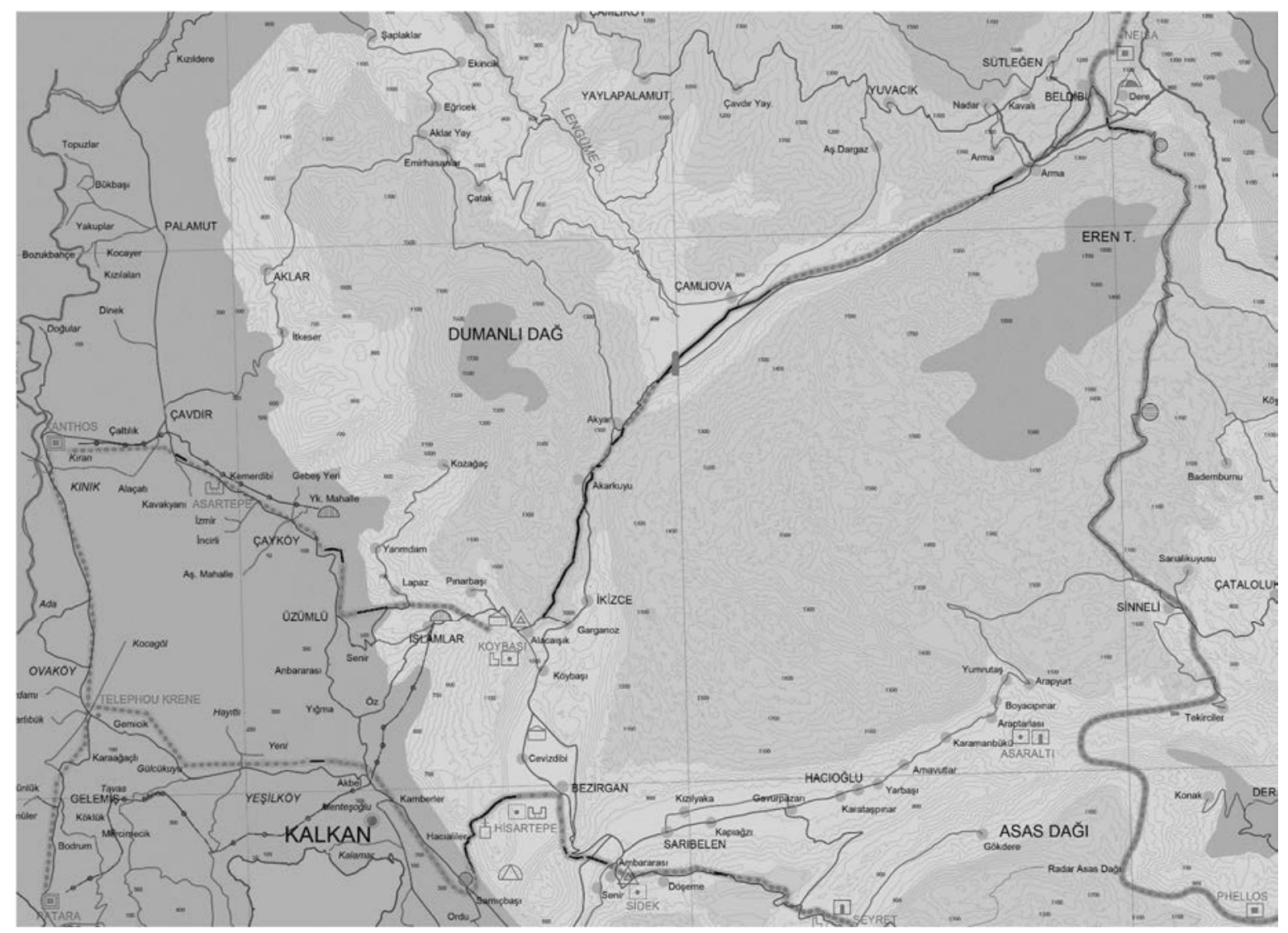

Fig. 1) The road from Xanthos to Neisa as given by Şahin (2014)

The number POF (176) at the end of the line reading from Xanthos to [Neisa] is quite secure, as can be seen at the end of the first line in Fig. 2 below. The destination also appears to have been correctly restored, as Neisa fills perfectly in the blank and the next road begins from Neisa, creating a link from the Xanthos Valley to Mylias through Choma. So it is evident that attributing this problem to a lapsus calami or a reading error can only be the last resort in offering a solution.

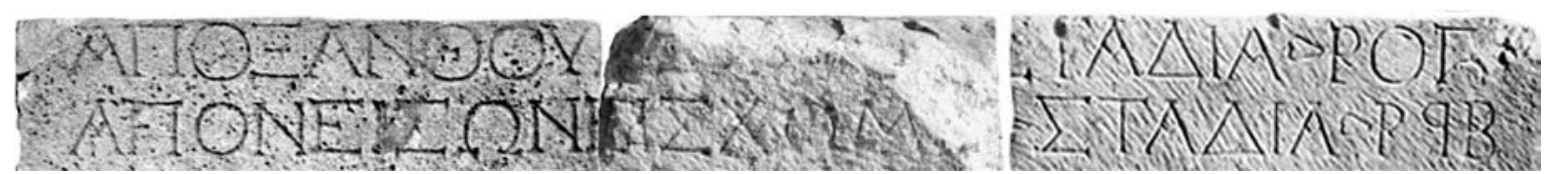

Fig. 2) The lines concerning Neisa in the SP (Şahin 2014, 146)

This assumption also causes some problems concerning the boundaries between Patara, Xanthos and Neisa. Şahin, since we had accepted that the road between Xanthos and Neisa in SP led through Alacaışı Pass on the northern slope of Köybaşı, claimed that Köybaşı settlement should have been situated within the territory of Xanthos ${ }^{4}$, contra Zimmermann and Schuler, who considered the settlement to lie within the territory of Patara. ${ }^{5}$ But the Xanthian affiliation of Köybaşı by the date of the SP can only be valid only if this road of SP was identical with the course given in the map above

\footnotetext{
${ }^{4}$ Şahin 2010, 141-143; cf. Onur - Alkan 2011, 67 fn. 5.

${ }^{5}$ Zimmermann 1992, 57; Schuler 2010, 81-85.
} 
(Fig. 1), since the road between Xanthos and Neisa should have led only through the territories of these two settlements, according to the basic principle of SP. ${ }^{6}$

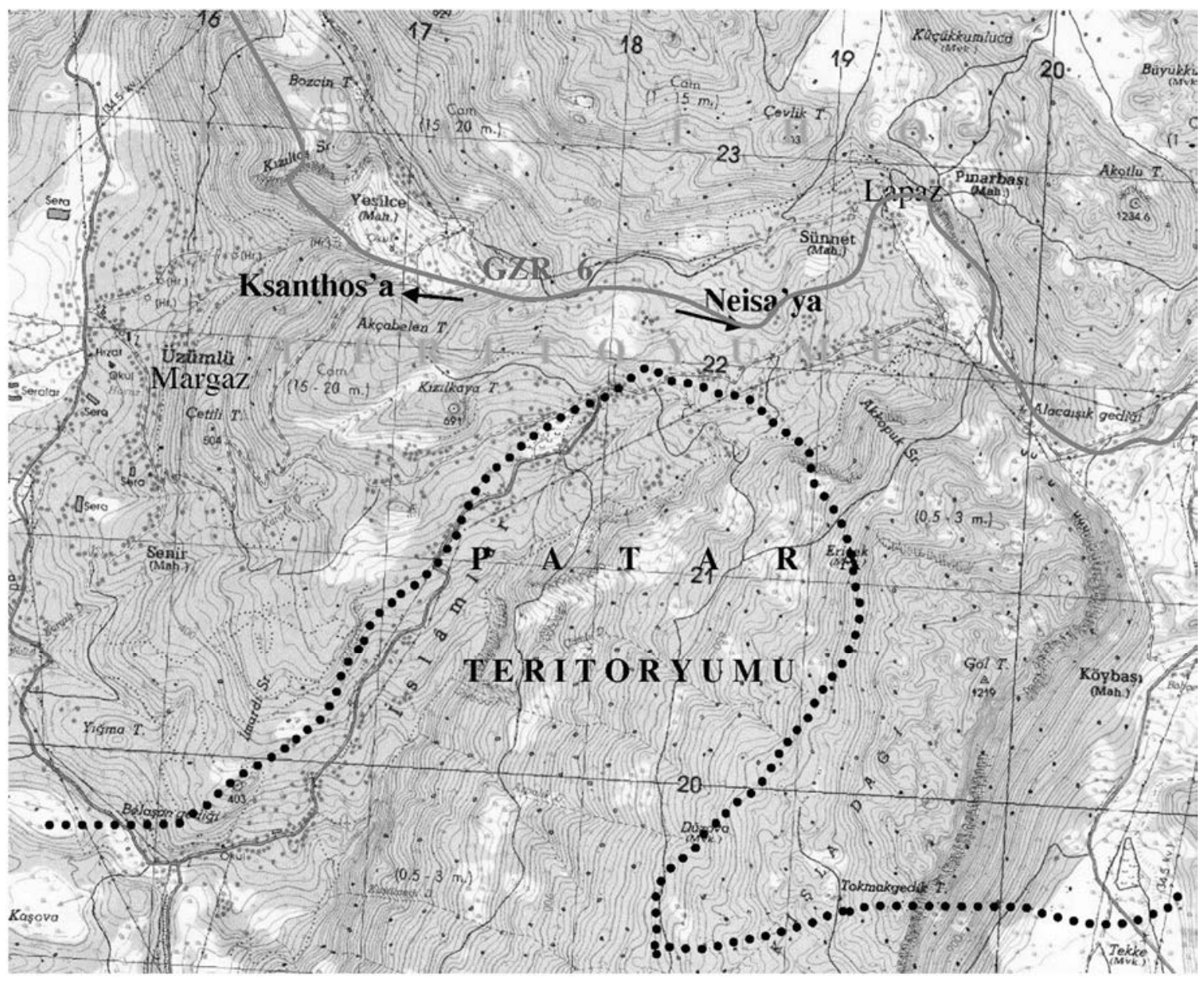

Fig. 3) The territorial borders between Xanthos and Patara proposed by Şahin 2014, 350, a.

However, this course presents a territorial problem concerning the boundary between Patara and Xanthos in the area around Köybaşı Hill (Kışla Dağı). Şahin accepted that only a small section around İslamlar, on the western slope of Köybaşı where the water sources of Patara rise, belonged to Patara, while the rest of Köybaşı Hill, the northern part of Bezirgan, Lapaz and Margaz to the west belonged to Xanthos (see Fig. 3).7 A funerary inscription from the Öz district of İslamlar, which records that the fine for tomb violation was to be paid to the polis of Patara, also provides evidence for the Pataran affiliation of this region. ${ }^{8}$ Further, the entire Bezirgan plain was also most probably within Pataran territory, as an inscription from Ambararası in Bezirgan informs us of an Euelthon, who is from Patara and "accomplished every official duty towards his motherland". ${ }^{9}$ So it does not seem satisfactory to assume Köybaşı was within the territory of Xanthos, since Köybaşı Hill itself would have remained within Xanthian territory, while it would have been surrounded by the territory of Patara to the east and to the west (see Fig. 7). The most plausible solution for these

\footnotetext{
${ }^{6}$ Onur - Alkan 2011, 67 with fn. 5; Onur 2016.

${ }^{7}$ See the map in Şahin 2010, 152 and 2014, 350, a (= Fig. 3 above).

${ }^{8}$ Onur - Alkan 2011, 66-67 no. 1.

${ }^{9}$ Onur - Alkan 2011, 68-69; cf. Zimmermann 1992, 57 and Şahin 2010, 141.
} 
discrepancies is actually to consider that the route through İslamlar and Alacasşık was not in fact the course of the road between Xanthos and Neisa recorded on the SP. The only option, which can cover these eventualities, in particular the distance recorded on the SP, was a mountain road. Therefore, it became necessary to investigate these issues in the field. In an excursion to the region, we found satisfactory answers and observed that there were different roads that were shorter than that which had been proposed.

To the east of Xanthos is the mountain called Dumanlı Dağ, of which the highest peak is ca. $1924 \mathrm{~m}$ (see Fig. 5 and Fig. 6). Crossing this mountain provides the only possibility of reaching Neisa by a shorter distance, as is recorded in the SP. There are two passes over this mountain. One is through nearby Aklar, where there is an ancient settlement on Asarcik which had been inhabited from Classical to the East Roman/Byzantine periods (Fig. 8-Fig. 11) and which belonged to Xanthos, as is shown by the honorary inscriptions in Asarcik which mention the Xanthian boule and demos. ${ }^{10}$ The ancient course of this road can still be observed ca. $600 \mathrm{~m}$ to east of the modern stabilized road that leads from Aklar to Yayla Aklar through a plain called Tavşan Yaylası (Fig. 12-Fig. 14). From Yayla Aklar there are two directions, one to Lengüme and another to Saklıkent, the former being the possible option for Neisa. But, this road, the highest point of which is ca. $1200 \mathrm{~m}$ in the Tavşan Plain, takes a northern course, arriving near Lengüme after $24-25 \mathrm{~km}$, and the distance is therefore too long for the route to Neisa. Its direction is also more convenient for a route to Arsada (Arsaköy) and then to Tlos, most probably crossing the deep gorge of the Deliçay at the location of the modern bridge called Toçak Köprüsü, which also connects Arsaköy (Arsada) and Sütleğen (Neisa). ${ }^{11}$ There is also a shorter modern road to the north, connecting Arsaköy and Sütleğen passing Karaçay/Deliçay and leading through Yuvacık, but this route would not have been preferred in antiquity in particular during the rainy winter and in the spring snow melt season due to the great floods of the Karaçay/Deliçay. ${ }^{12}$

A shorter and more plausible road is that which crosses the mountain via the Duman Pass, which is right on the line extending from Xanthos to Neisa (see Fig. 5). This road, after leaving Xanthos, should have reached the slopes passing directly through Çavdır, where two milestones, one of which dates from the Tetrarchic period, were found. ${ }^{13}$ Then it probably took the course of the modern road leading to Aklar, but then turned east after ca. $3 \mathrm{~km}$ near the neighbourhood of İtkeser immediately before the neighbourhood of Sahil Aklar, and before reaching Aklar, which is at ca. $2 \mathrm{~km}$ north of this point. After passing Armutçukuru and three large Ottoman cisterns around it by the road between İtkeser and Duman Spring, indicating the subsequent traditional use of this route, the road reaches a place called Duman Spring (Fig. 19). At Duman Spring, where there are several ancient ruins, including a sarcophagus (Fig. 20-Fig. 21) and the remains of farmsteads and terraces

\footnotetext{
${ }^{10}$ See for the archaeological remains and the inscriptions (by Recai Tekoğlu) in Işık 2010; In the field surveys led by the Canadian Epigraphic Mission at Xanthos-Letoon in Aklar - Asarcık, 5 inscriptions were discovered in 2010, see Courtils 2011, 340 and http://www.xanthos.hst.ulaval.ca/eng/2010_eng.htm. For this reason, we did not conduct epigraphic research in this settlement.

${ }^{11}$ Zimmermann 1992, 238; Hellenkemper - Hild 2004, 266; Takmer - Oktan 2013, 65; Şahin 2014, 152 with fn. 193.

${ }^{12}$ For Karaçay/Deliçay see Şahin 2009, 343-344 (= Şahin 2012, 13-14 in Turkish).

${ }^{13}$ Baker and Thériault in: Courtils 2008, 377; Cavalier - Courtils 2008, 390 and Fig. 14; French 2014, 59 nos. 24(A) and 24(B).
} 
(Fig. 19), the ancient road led to another terraced plain 350-400 $\mathrm{m}$ to east. The old retaining walls of the road can be more clearly followed (Fig. 22-Fig. 26) from this place to the Duman pass. At the pass the road continues in two directions, one running north to the Toçak bridge and Yayla Aklar, from where it reaches Saklıkent, while the other, the ancient road to Neisa, takes an eastern course. The retaining walls are still visible today on the pass and there are some ancient ruins by the road after $2 \mathrm{~km}$ on the eastern side of Mount Dumanl. The remains of a broad wall, after a place called Şirlengiçpınar, extending at a right angle to the road suggests that it belonged to a building which may have been designed to control traffic along the road (Fig. 27). There were probably two routes which branched $1,5 \mathrm{~km}$ beyond this point: one continued south to reach the southwestern point of Lengüme, joining the road which eventually arrives in Patara; the other led east as directly as possible to reach Neisa through İğrice, and perhaps Çamliyurt on the northern slopes above Lengüme. This course starting from Xanthos and reaching Neisa has a maximum length of 33-34 km with an average incline of \% 8.9 (Google Earth), which is slightly longer than the distance recorded on the SP. This seems to support that the measurement of the road started and ended on the borders of the town zones of Xanthos and Neisa, indicating that there were some spaces between city centers and the starting/ending points of measurement of the roads.

The last problem in this proposal concerns the milestone at the southeastern point of Lengüme (see above fn. 3) and with the territorial affiliation of Lengüme itself. Since it is best to assume that in order to conform with the distance given in the SP the road to Xanthos ran from north of Lengüme, there remains no reason to assume that the destination recorded on the milestone was Xanthos. Even though from this point to Xanthos through the Duman Pass more or less meets the distance given on the milestone (16 MP = ca. $23 / 24 \mathrm{~km}$ ), it does not make sense to give the distance to Xanthos from this point instead of the northern point of Lengüme, which has much closer access to the Duman Pass. If the destination was not Xanthos, then only one option remains, that of Patara. Firstly, the distance matches the length of the road to Patara from this point, following a route which runs through Akarkuyu, the western vicinity of İkizce, Alacaışı Pass by Köybaşı/Gölbaşı, İslamlar (Bodamya), Yeşilköy (Fırnaz) and finally the Kısık Pass. There might have also been shorter passages from the Alacaışı Pass to Yeşilköy, through a point between İslamlar and Üzümlü (Margaz), as the locals relate. This connection should be the road leading from Patara to the northeast drawn in Tabula Peutingeriana, ${ }^{14}$ as an important connection to the Mylias. Secondly, it does not make sense if the exit from the southwestern point of Lengüme had its destination at Xanthos, when there was already a road over Mount Dumanlı through the Duman Pass. Therefore, it would be much better to assume the distance on this milestone was from Patara and the inscription can be

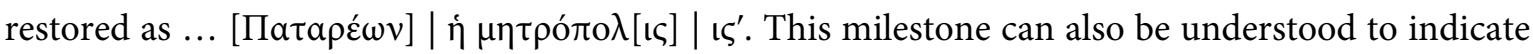
the territorial extent of Patara, which would in this case have reached at least to this point. Consequently, there is no reason today to assume that Köybaşı was within the territory of Xanthos, since the course proposed formerly has been shown to have been incorrect. On the contrary, assuming the region around Köybaşı was within the territory of Patara removes the complexities concerning the territories of these two cities in this region. The territory of Patara seems to have reached today's Üzümlü/Margaz, from where an unpublished funerary inscription located $2-3 \mathrm{~km}$ south of the Xanthos water canal, which records a fine addressed to Patara, has been found. ${ }^{15}$

\footnotetext{
${ }^{14}$ Tab. Peut. X.2; French 1995, 3; cf. Şahin 2014, 146.

${ }^{15}$ I thank Christof Schuler, who shared this information with me.
} 


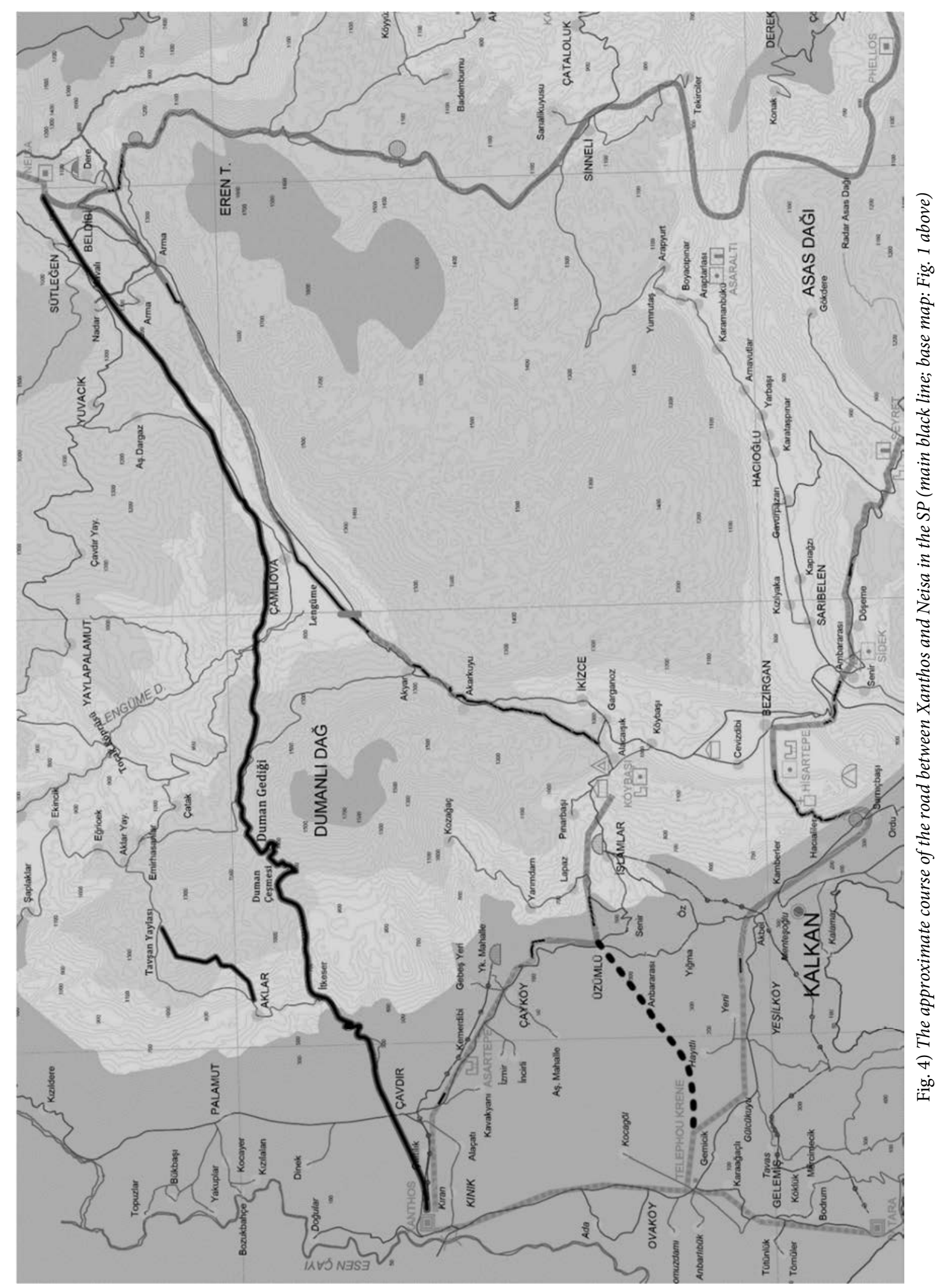


The affiliation of Lengüme remains somewhat unclear, as it may have belonged to any of three cities: Xanthos, Neisa and Patara (see Fig. 1 and Fig. 28). But there are some points which need to be taken into consideration in this matter. In the SP there is no road given between Patara and Neisa, this may have been because the territory of Xanthos might have lied between them and this territorial interference might well have been at Lengüme, suggesting that Lengüme might have remained within the territory of Xanthos. On the other hand, the SP does not necessarily list all the connections. Considering for example that there is no road recorded on the SP between Sidyma and Pinara, which were adjacent and much closer to each other than Patara and Neisa, it is also possible to consider that the SP simply likewise omitted this road.

\section{Bibliography}

Cavalier - Courtils 2008

C. Laurence - J. des Courtils, Nécropole antique ou cimetière moderne? Vestiges funéraires dans les environs de Xanthos, Anatolia Antiqua 16/1, 2008, 381-392.

Courtils 2008

J. des Courtils, Xanthos 2007, Anatolia Antiqua 16/1, 2008, 365-379.

Courtils 2011

J. des Courtils, Xanthos. Rapport sur la campagne 2010, Anatolia Antiqua 19/1, 2011, 321-350.

French 1995

D. French, 1994 Araştırma Döneminde Roma Yolları, Miltaşları ve Yazıtları, AST 13/1, 1995, 1-6.

French 2014

D. French, Roman Roads \& Milestones of Asia Minor. Vol 3 Milestones, Fasc. 3.6 Lycia et Pamphylia, Ankara 2014 (E-book by BIAA).

Hellenkemper - Hild 2004 H. Hellenkemper - F. Hild, Lykien und Pamphylien [Tabula Imperii Byzantini 8], Vol. I, Vienna 2004.

Işık 2010

F. Işık, Das Leto-Heiligtum in Asarcık am Xanthostal Zur sog. Akkulturation in Lykien anhand seiner fruhen Tempelbauten, IstMitt 60, 2010, 81-115.

Onur - Alkan 2011

F. Onur - M. Alkan, Parerga to the Stadiasmus Patarensis (6): Route 54 (Patara - Phellos) and New Inscriptions, Gephyra 8, 2011, 64-80.

Onur 2016

F. Onur, Parerga to the Stadiasmus Patarensis (16): The roads, settlements and territories, Gephyra 13, 89-117.

Şahin - Adak 2007

S. Şahin - M. Adak, Stadiasmus Patarensis. Itinera Romana Provinciae Lyciae, İstanbul 2007.

Şahin 2009

S. Şahin, Kragos Oros, Titanis Petra und der Apollontempel von Patara. Lokalisierungsversuche in der historischen Geographie Lykiens, in: E. Olshausen - V. Sauer (edd.), Die Landschaft und die Religion. Stuttgarter Kolloquium zur Historischen Geographie des Altertums 9, 2005 (Geographica Historica Band 26), 2009, 337-352.

Şahin 2010

S. Şahin, Parerga zum Stadiasmus Patarensis (3): Die Inschrift von Köybaşı in Zentrallykien, Gephyra 7, 2010, 137-152.

Şahin 2012

S. Şahin, Kragos Oros, Titanis Petra ve Patara Apollon Tapınağı. Lykia'nın Tarihi Coğrafyasına İlişkin Bir Lokalizasyon Denemesi, 
Şahin 2014

Schuler 2010

Takmer - Oktan 2013

Zimmermann 1992

in: N. E. Akyürek Şahin - B. Takmer - F. Onur (edd.), Eskiçağ Yazıları 3, İstanbul 2012 (AKRON 3), 1-28.

S. Şahin, Stadiasmus Patarensis. Itinera Romana Provinciae Lyciae / Likya Eyaleti Roma Yolları (Tarihi İçerik: M. Adak), Istanbul 2014.

C. Schuler, Priester $\pi \rho o ̀ ~ \pi o ́ \lambda \varepsilon \omega \varsigma$ in Lykien: Eine neue Inschrift aus dem Territorium von Patara, ZPE 173, 2010, 69-86.

B. Takmer - M. Oktan, Parerga zum Stadiasmus Patarensis (11):

Die lykische Stadt Neisa, Gephyra 10, 2013, 50-96.

M. Zimmermann, Untersuchungen zur historischen Landeskunde

Zentrallykiens, Bonn 1992.

Parerga to the Stadiasmus Patarensis (17): Ksanthos - Neisa Yolunun Güzergâhı için Düzeltme Özet

Stadiasmus Patarensis (SP) listesinde Ksanthos ve Neisa arası 176 stadion (yak. 32-33 km) olarak verilmiştir. 2009-2010 çalışmalarımızda bu yolun İslamlar, Köybaşı altındaki Alacaışık Gediği, Lengüme üzerinden geçtiği kabul edilmişti. Fakat böyle bir yol en az 39-40 km tutmakta ve bu da SP’te verilen mesafeyi çok aşmaktadır. Sencer Şahin yolun yukarıda bahsi geçen güzergâhtan gittiğini kabul etmekle, Köybaşı'nı da Ksanthos teritoryumuna yerleştirmiş oluyordu, çünkü SP’nin özelliği olarak yolun sadece Ksanthos ve Neisa teritoryumlarından geçmesi gerekiyordu. Dolayısıyla, böyle bir yolun kabulü hem mesafenin çok fazla fark arz etmesi hem de doğu (Bezirgân) ve batı (İslamlar) yakaları Patara’ya ait olan Köybaşı'nın Ksanthos'a ait algılanması gibi sorunlar ortaya çıkarmaktadır. Bu duruma çözüm, ancak çok daha kısa ve dağdan giden bir yol olabilirdi. Bu bağlamda yaptığımız araştırmalarda, gerçekten de Aklar’a varmadan onun $2 \mathrm{~km}$ güneyinden doğrudan doğuya yönelerek Duman Gediği denilen yerden geçen bir yol tespit edildi. Bu güzergâhın yukarı kısımlarında ve dağın doğu yüzünde yolun izleri hâlâ durmaktadır. Bu yol doğrudan Lengüme'nin kuzey ucuna yakın bir yerden Neisa'ya ulaşmalıdır. Yolun uzunluğu da aşağı yukarı 33 km kadar olup, SP ile uyum içindedir. Böylelikle SP’te verilen Ksanthos ve Neisa arasındaki antik yolun İslamlar ve Köybaşı'ndan geçmediği anlaşılmış, sonuç olarak da Köybaşı'nın Ksanthos teritoryumunda kalması gibi bir zorunluluk da ortadan kalkmıştır. Aksine, hem doğusundaki Bezirgân hem de batı yamacındaki İslamlar Patara teritoryumunda olan Köybaşı'nın kendisinin de Patara teritoryumunda olması bölgedeki teritoryum sorununu da ortadan kaldırmıştır. Konuyla ilgili diğer sorun da Lengüme'nin batı ucunda bulunan mil taşıydı. Bu mil taşında ismi günümüze ulaşmamış olan bir "metropolis"e 16 MP (yak. $24 \mathrm{~km}$ ) mesafe verilmektedir. Şimdiye kadar bu metropolis 1srarla Ksanthos olarak kabul edilmişti. Fakat bu makalede konu edilen dağ yolu nedeniyle, Neisa'dan ya da Lengüme'den doğrudan Ksanthos'a gitmek için Lengüme'nin güneybatı çıkışını kullanmak uygun görünmemektedir, zira Lengüme'nin kuzey ucuna yakın bir yerden zaten doğrudan Duman Gediği'ne çıkılabilmektedir. Bu durumda mil taşındaki kent Ksanthos değilse, onun yerine verilebilecek tek cevap Patara'dır. Mil taşındaki aşağı yukarı 24 km'lik mesafe, mil taşının durduğu yerden Patara’nın kent sınırına kadar olan mesafeyla uyum içindedir. Yerli halkın söylediğine göre İslamlar ve Margaz arasından inen kestirme eski yollar bulunmaktadır. Dolayısıyla bu mil taşında verilmiş olan mesafenin başlangıç noktasının Patara olduğunu düşünüyorum. Bu da bizi Patara teritoryumunun en azından Lengüme'nin batı ucuna kadar ulaşmış olduğu sonucuna götürmektedir. Lengüme'nin 
kendisinin Ksanthos, Neisa veya Patara kentlerinden hangisine ait olabileceğine dair doğrudan bir delil maalesef yoktur. Fakat SP'te Patara ve Neisa arasında bir yolun olmaması, araya giren Ksanthos teritoryumu ile ilgili olabilir, eğer böyleyse Lengüme Ksanthos teritoryumunda kalacaktır. SP'te böyle bir durumda yol vermek istense "Patara'dan Neisa'ya Ksanthos üzerinden" ifadesi beklenebilirdi ama araya büyük kentlerin teritoryumları girince SP’te genelde yol verilmemektedir. Bu anlamda, Korydalla - Akalissos yolunda verilen Rhodiapolis bilgisi tek örnektir (fakat Rhodiapolis'in en azından Claudius Dönemi'nde Patara ve Ksanthos ile kıyaslanamayacağı açıktır). Bununla birlikte, SP her kent arasında yol vermemektedir; örneğin Sidyma ve Pinara arasında, Patara ve Neisa'ya kıyasla çok daha yakın komşu kentler olmalarına rağmen, bir şekilde bir yol verilmemiştir. Dolayısıyla SP olası Patara ve Neisa arasındaki bu yolu listeye dâhil etmemiş de olabilir.

Anahtar Sözcükler: Ksanthos; Neisa; Dumanlı Dağ; Patara; Köybaşı; Lengüme/Çamlıva; Bezirgân.

\section{Parerga to the Stadiasmus Patarensis (17): A Correction to the Course of the Road between Xanthos and Neisa} Abstract

The distance between Xanthos and Neisa in the Stadiasmus Patarensis (SP) is given as 176 stadia (ca. 32-33 km). As the results of our field surveys in 2009-2010, it was accepted that this road led through İslamlar and the Alacaışı Pass directly below Köybaşı Hill. But such a route with a length of $39-40 \mathrm{~km}$ is much longer than that which the SP provides. Sencer Şahin, who accepted this route as the course of the road from Xanthos to Neisa in the SP, claimed that Köybaşı, of which both eastern (Bezirgan) and western parts (İslamlar) belonged to Patara, remained within the territory of Xanthos. Therefore, it was obvious that both the difference in distances and the territorial borders around Köybaşı present some problems. The only solution to these problems was a much shorter mountain route. In our recent field observations, we found a convenient road, which led to Neisa via the shortest possible course, over Mount Dumanl. This road reached Neisa from Xanthos through Çavdır, İtkeseri, Armutçukuru, Duman Spring, Duman Pass and the north of Lengüme. The length of this route is ca. $33 \mathrm{~km}$, which conforms with the distance recorded on the SP. In consequence therefore, as the road recorded on the SP was not through İslamlar and Alacasşı Pass by Köybaşı, there remained no reason to assume that Köybaşı was within the territory of Xanthos. On the contrary, accepting Köybaşı as being within the territory of Patara removes territorial problems in the related regions. A further problem concerning this issue is the milestone found at the southwestern point of Lengüme, from where the road leads to the Alacasşı Pass by Köybaşı. On this milestone a distance of $16 \mathrm{MP}$ (ca. $24 \mathrm{~km}$ ) is given from a "metropolis", which was accepted as Xanthos. But, since it is established that the road between Xanthos and Neisa took a mountain course passing through the norther point of Lengüme, the destination on the milestone would not have been Xanthos, but rather Patara, being the only option from the southwestern end of Lengüme. This distance of $16 \mathrm{MP}$ (ca. $24 \mathrm{~km}$ ) also conforms with the distance to Patara. The last question concerns the territorial affiliation of the land of today's Lengüme. Unfortunately, there is no direct evidence to affiliate it with any of the three possible options: Xanthos, Patara and Neisa. But, because there is no road given between Patara and Neisa on the SP, this might have been because the territory of Xanthos lay in between, and, if this were the case, the Lengüme Plain might well have belonged to Xanthos in antiquity. However, such a road might have been omitted from the SP as well, like the absence of record on the SP of a road between Pinara and Sidyma, even though they were closer neighbours.

Keywords: Xanthos; Neisa; Mount Dumanlı; Patara; Köybaşı; Lengüme/Çamlıva; Bezirgân. 


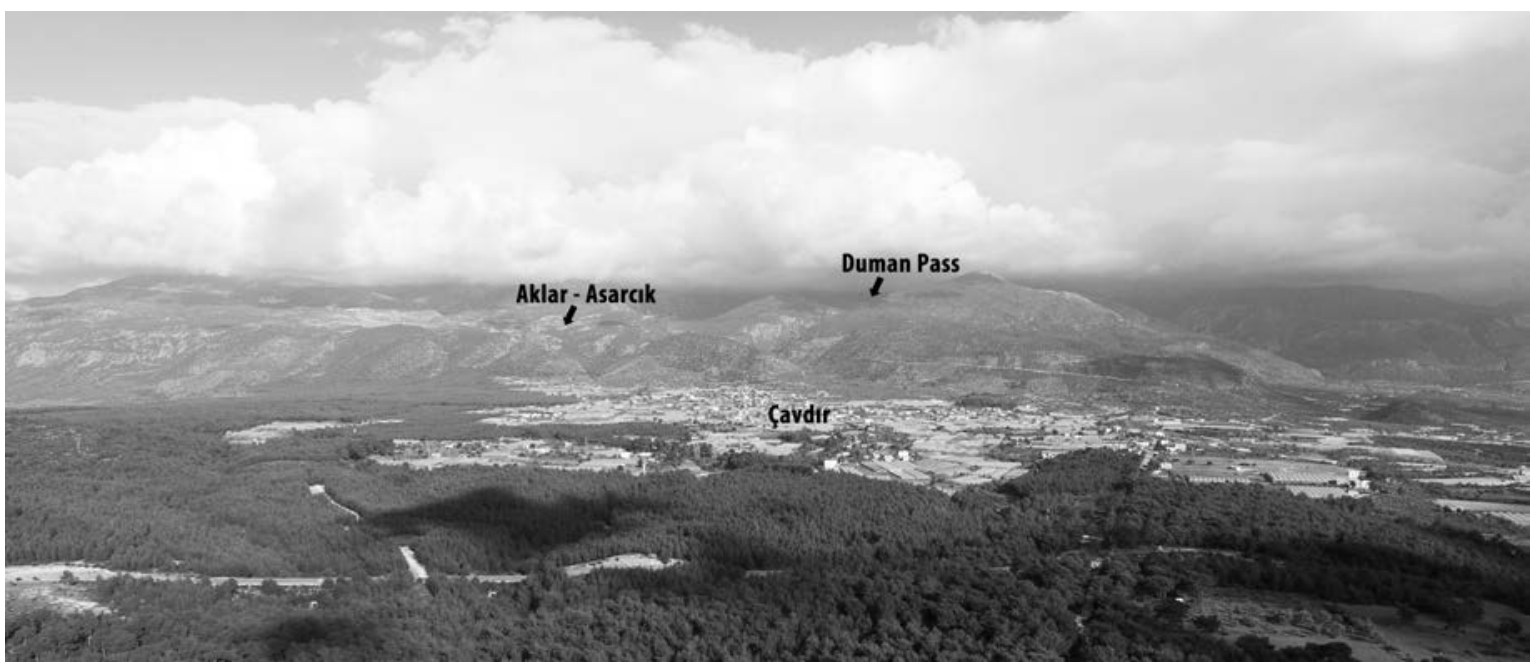

Fig. 5) Mount Dumanl (looking to the east from Xanthos)

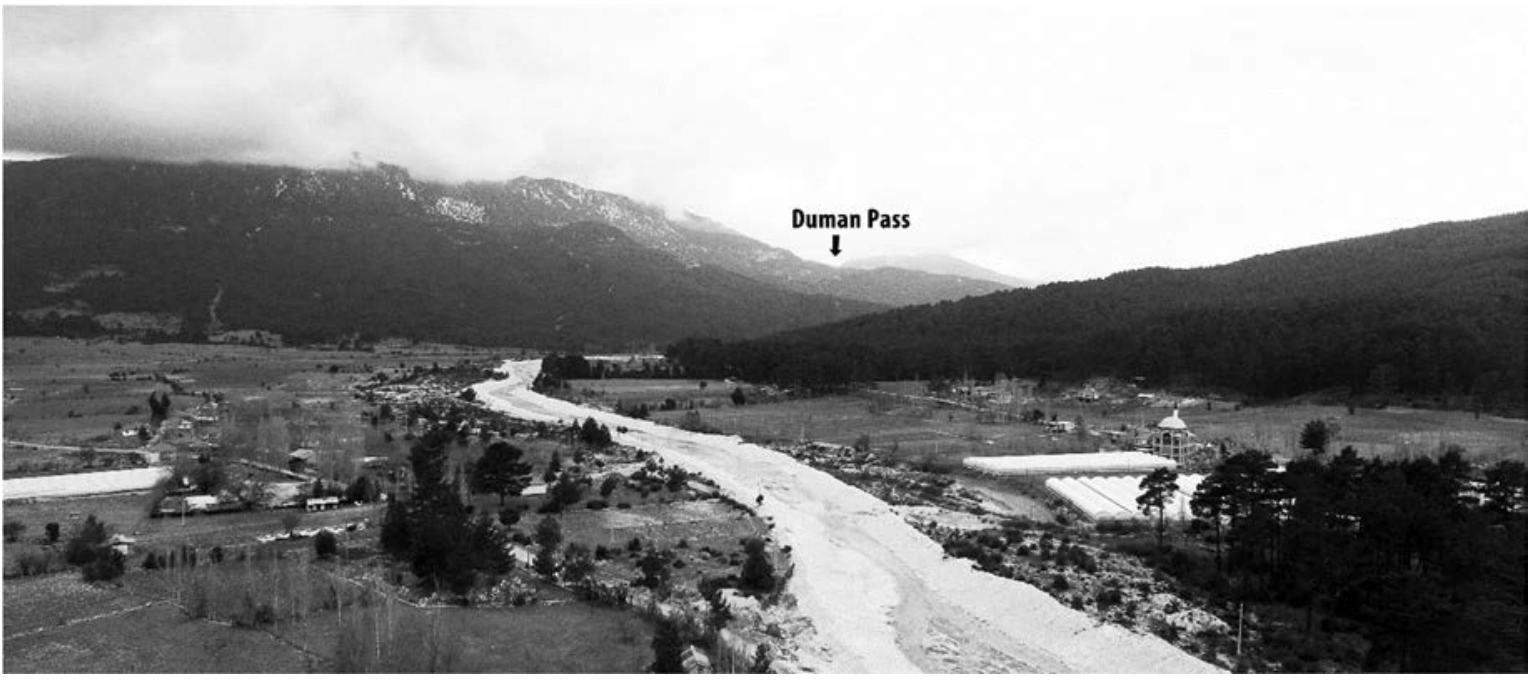

Fig. 6) Lengüme/Çamlıova and Mount Dumanlı (looking to the northwest from the direction of Neisa)

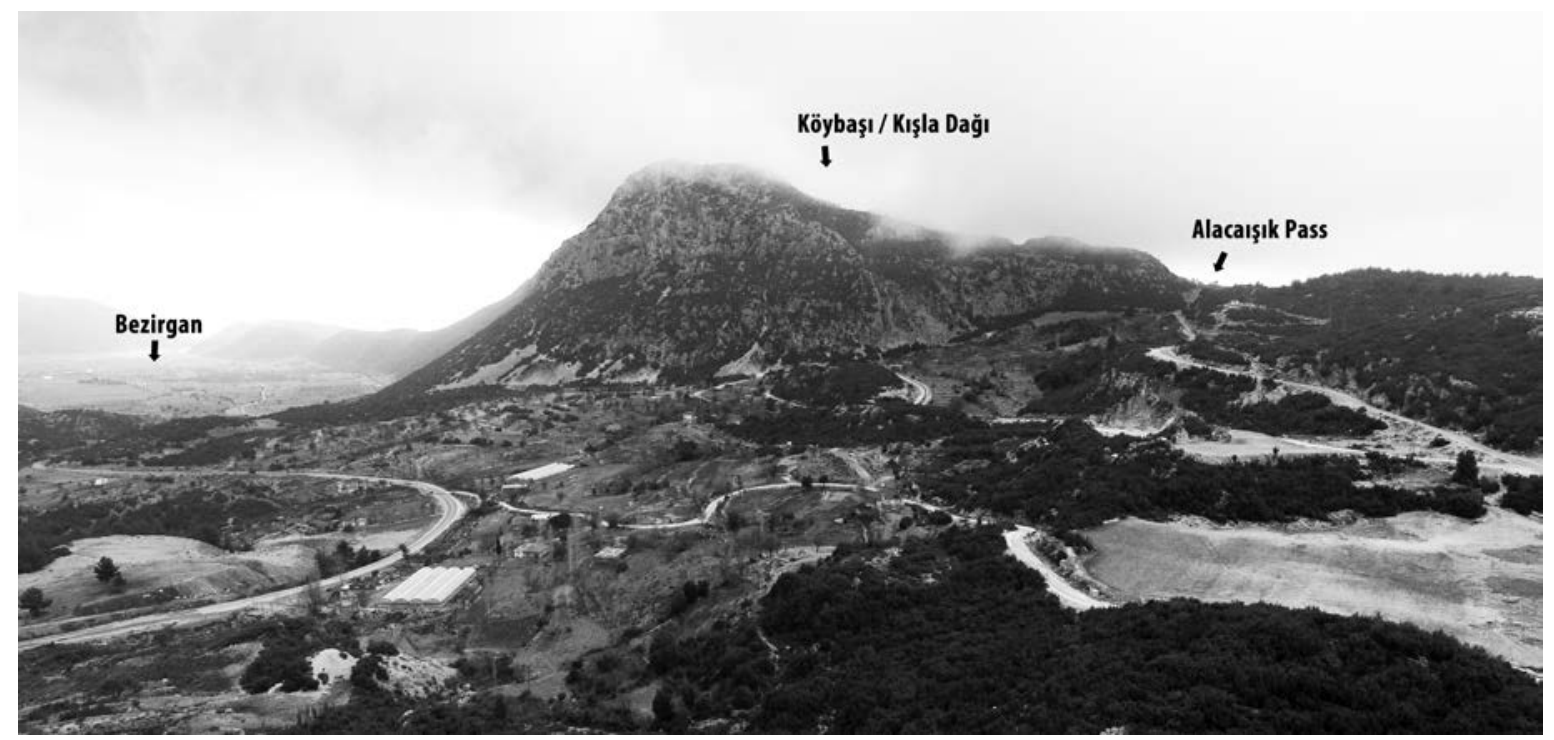

Fig. 7) Bezirgan, Köybaşı and Alacaışık Pass (looking to the southwest) 


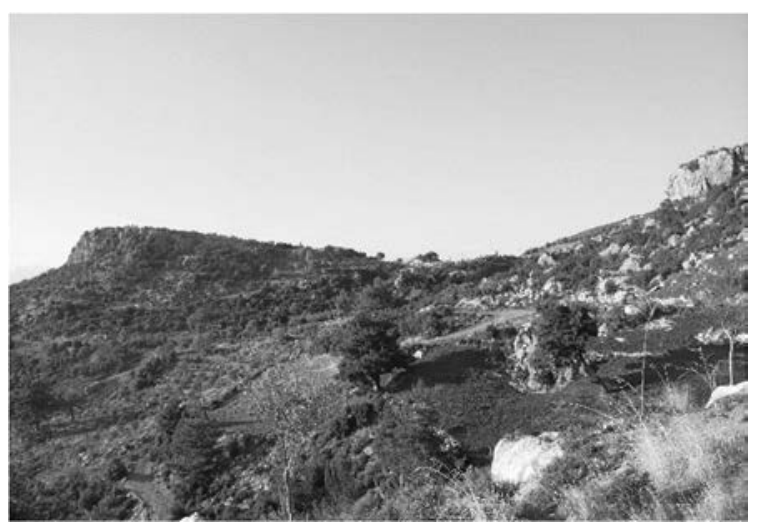

Fig. 8) Asarcık Hill, Aklar, view to the north.

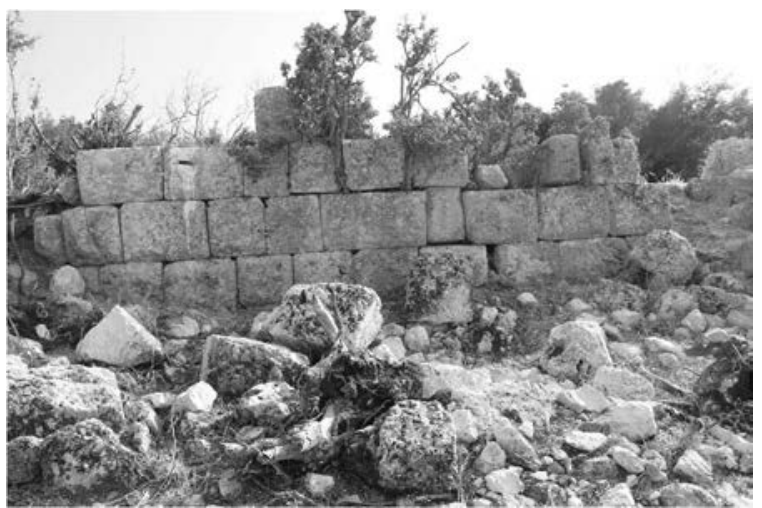

Fig. 10) Asarcık, Aklar.

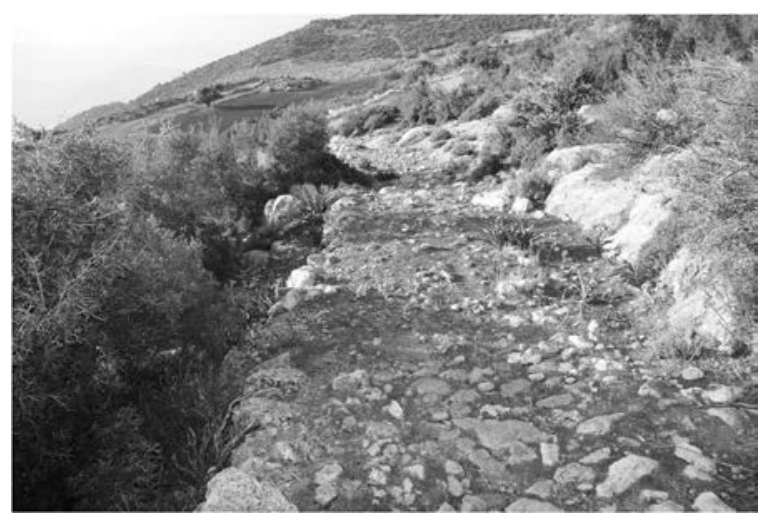

Fig. 12) The ancient road between Aklar and Tavşan Plain.

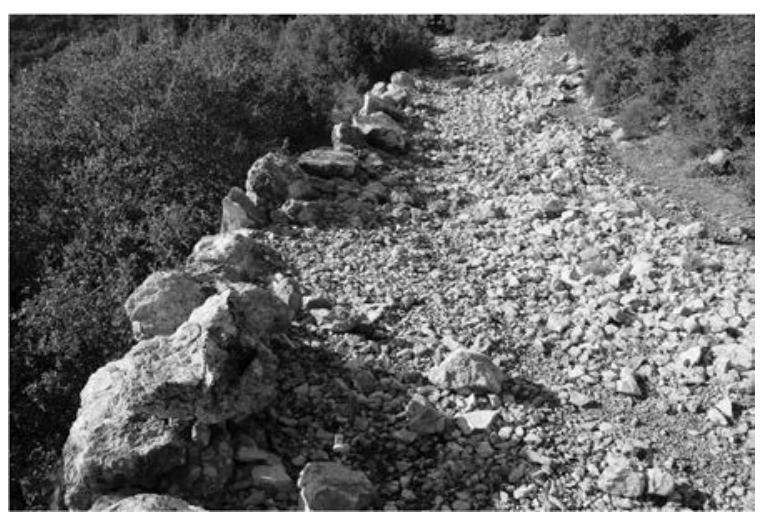

Fig. 14) The ancient road between Aklar and Tavşan Plain.

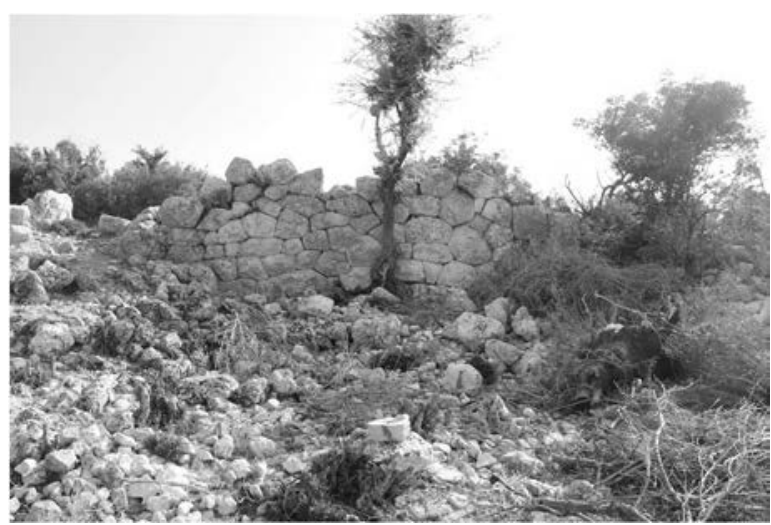

Fig. 9) Asarcık, Aklar.

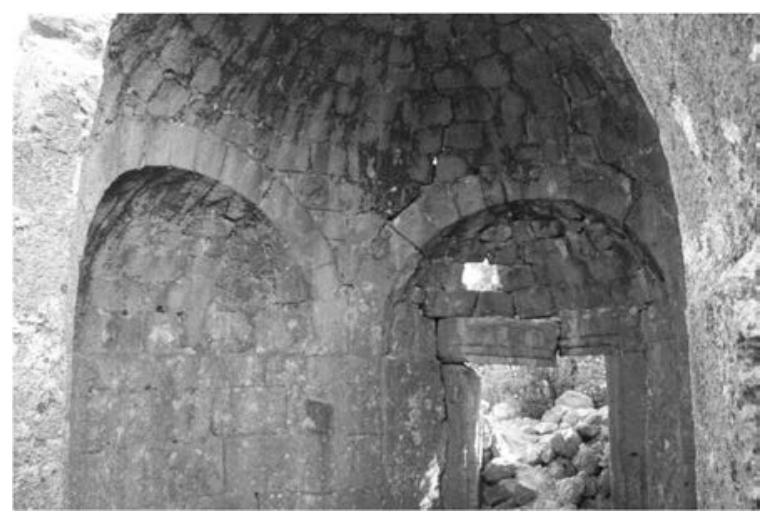

Fig. 11) Asarcık, Aklar. A martyrion?

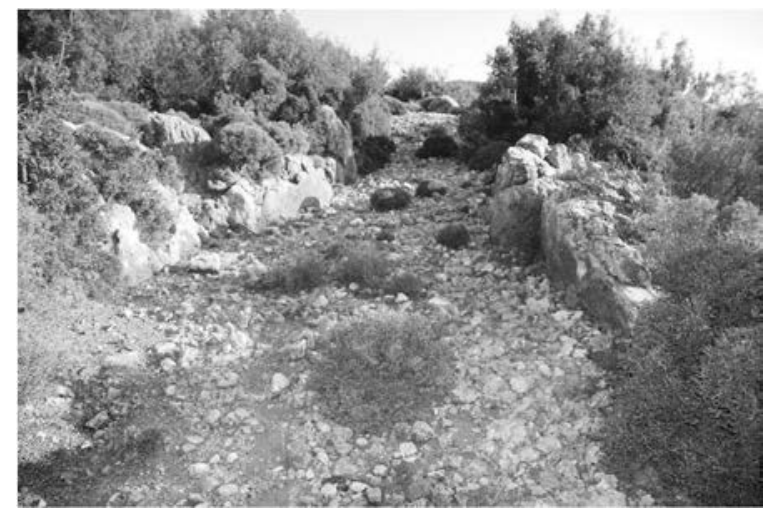

Fig. 13) The ancient road between Aklar and Tavşan Plain.

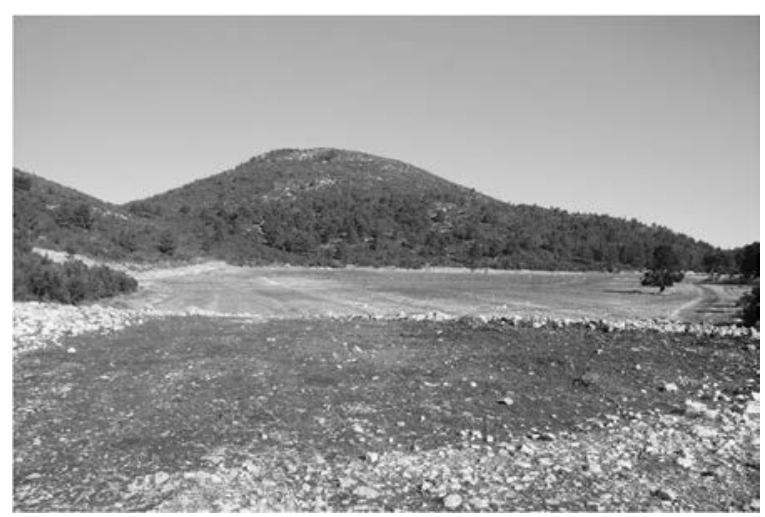

Fig. 15) The Tavşan Plain 


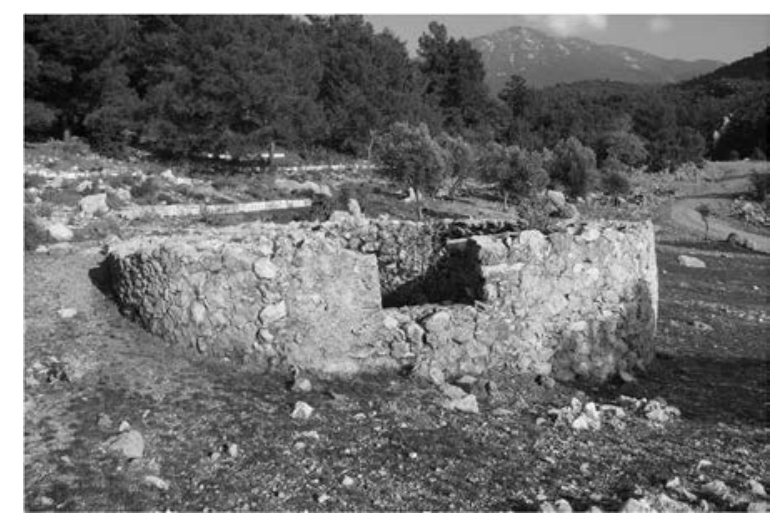

Fig. 16) The first Ottoman cistern on the way to Duman Pass

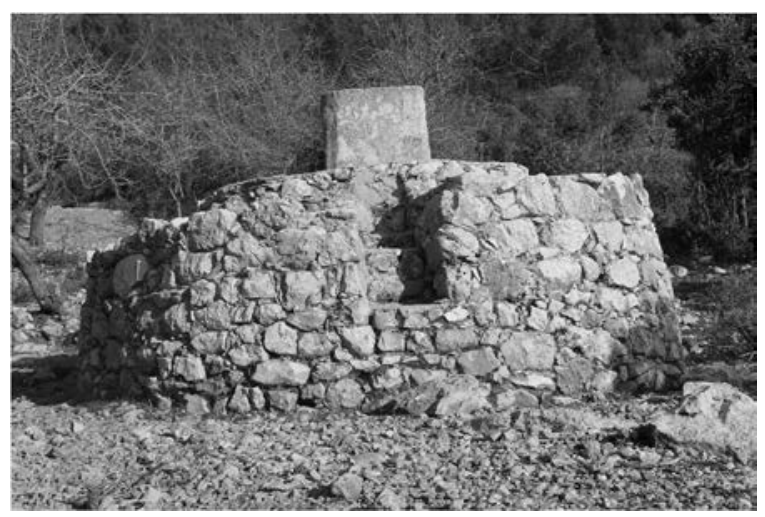

Fig. 18) The third Ottoman cistern on the way to Duman Pass

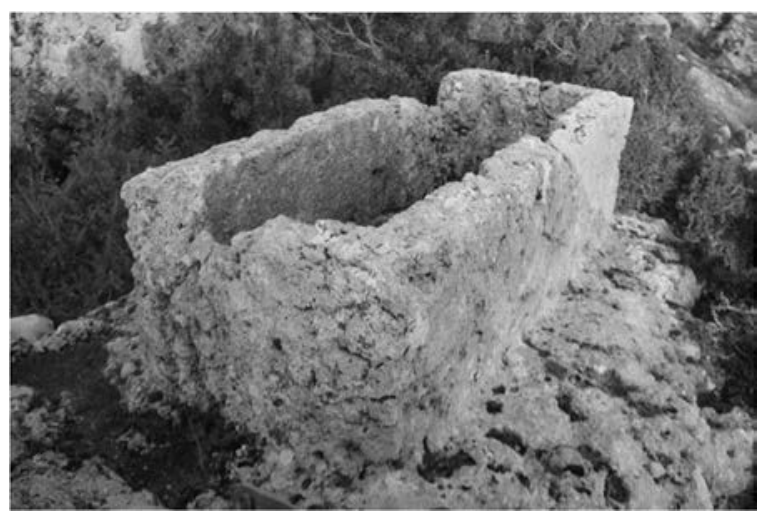

Fig. 20) The sarcophagus at Duman Spring

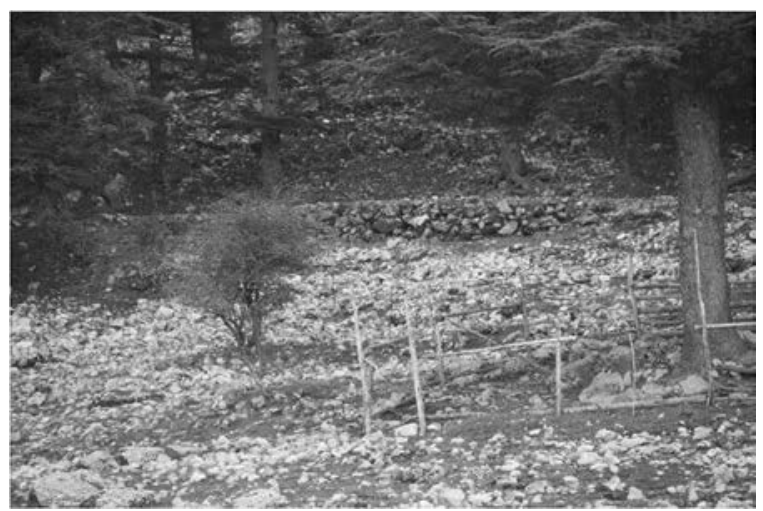

Fig. 22) Retaining walls of the road between Duman Spring and Duman Pass.

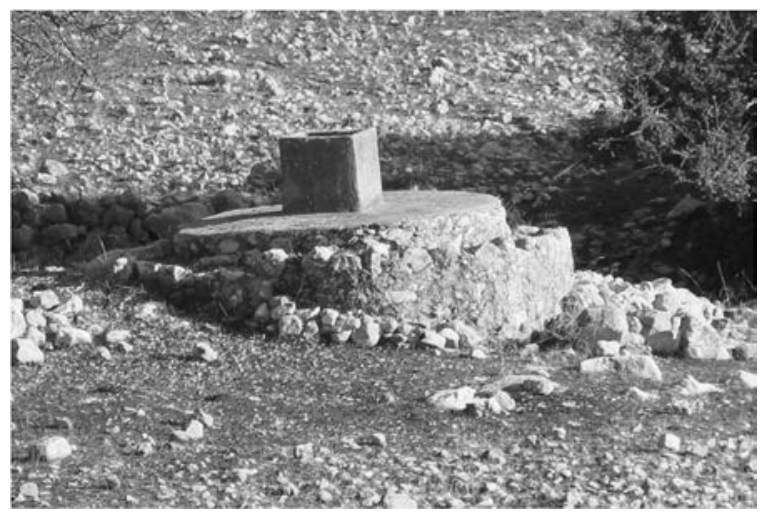

Fig. 17) The second Ottoman cistern on the way to Duman Pass

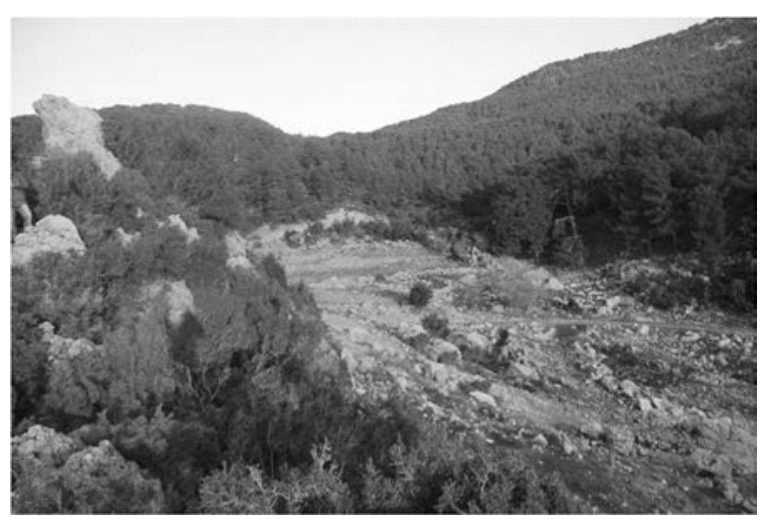

Fig. 19) Duman Spring, with Duman Pass at the back

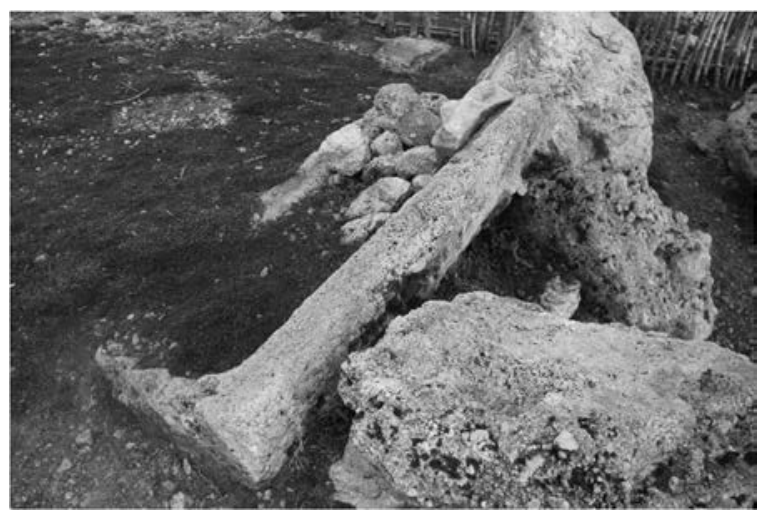

Fig. 21) The lid of the sarcophagus at Duman Spring

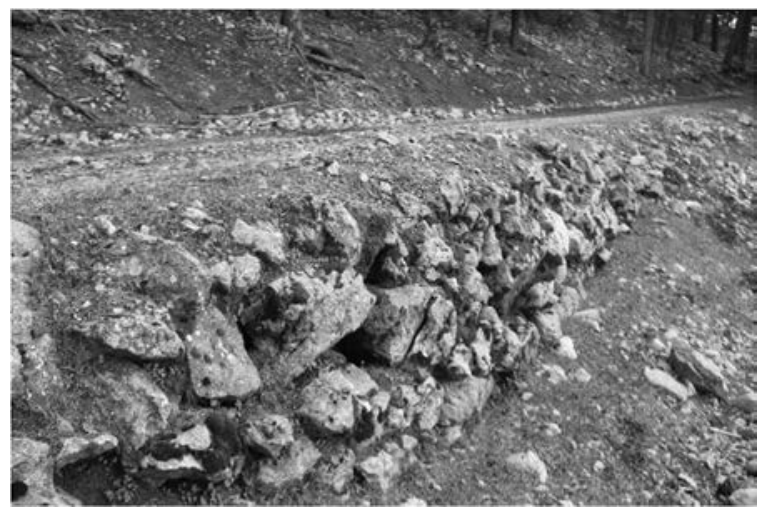

Fig. 23) Retaining walls of the road between Duman Spring and Duman Pass. 


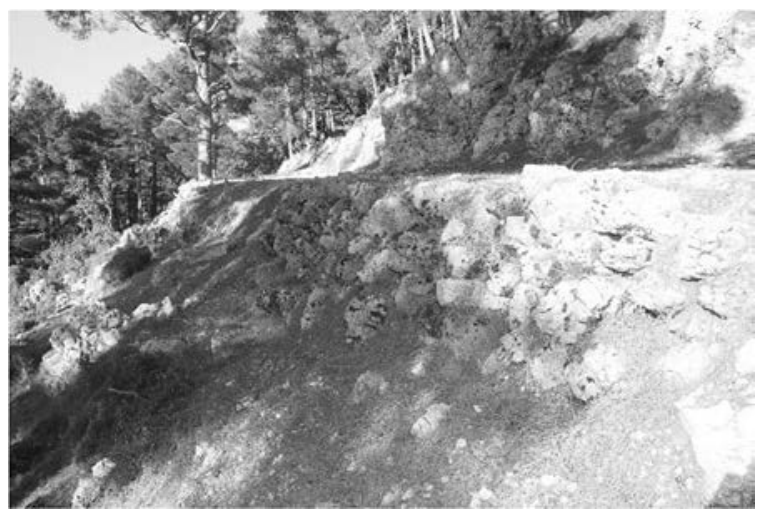

Fig. 24) Retaining walls of the road at Duman Pass.

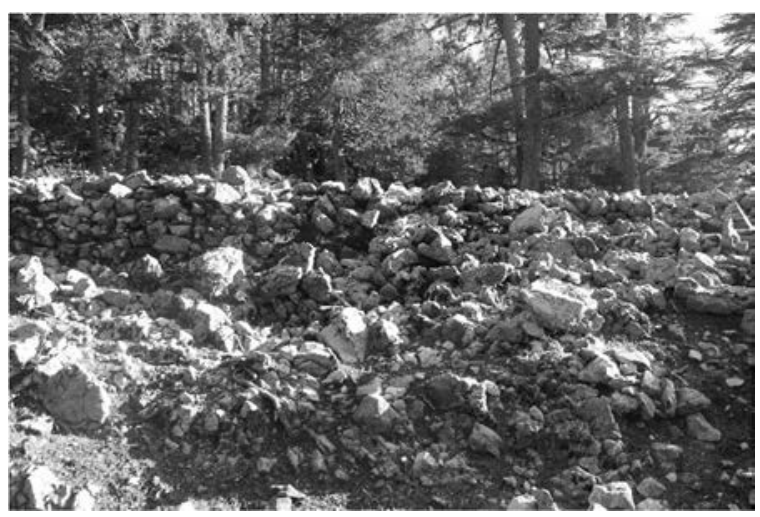

Fig. 26) Retaining walls of the road at Duman Pass.

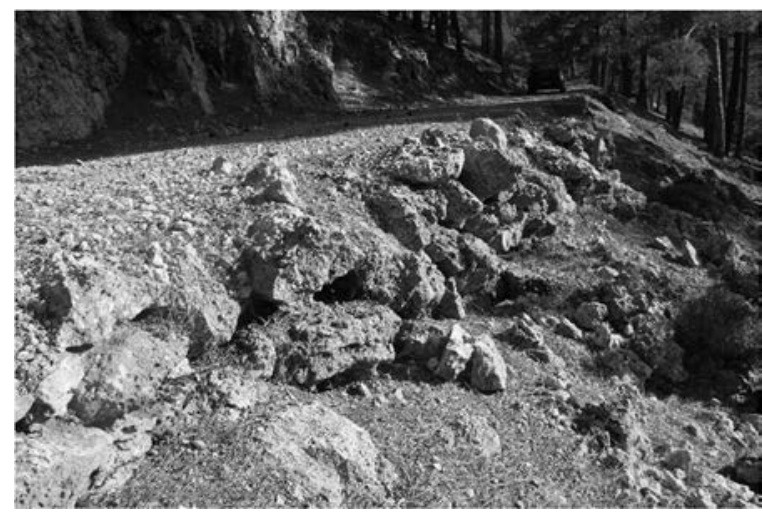

Fig. 25) Retaining walls of the road at Duman Pass.

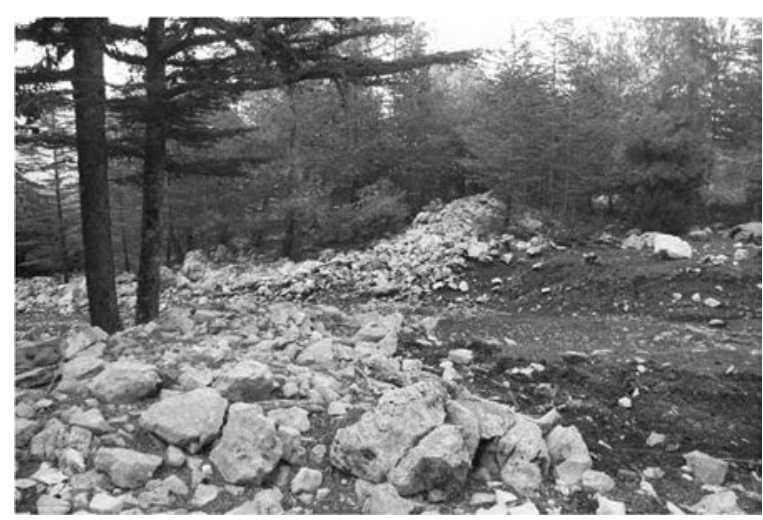

Fig. 27) The ancient road passing through the wall.

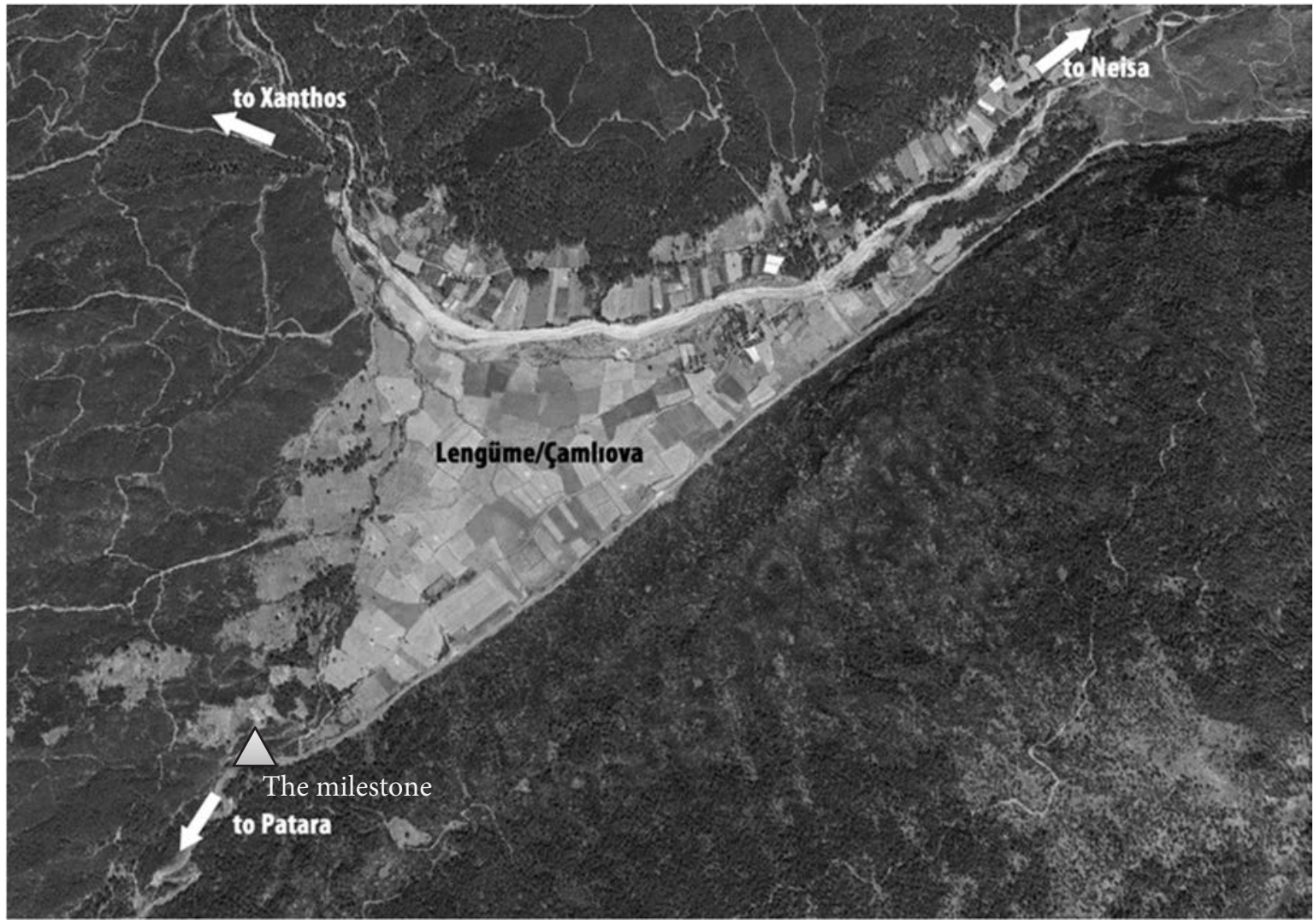

Fig. 28) Lengüme/Çamlıova (satellite image from Google) 

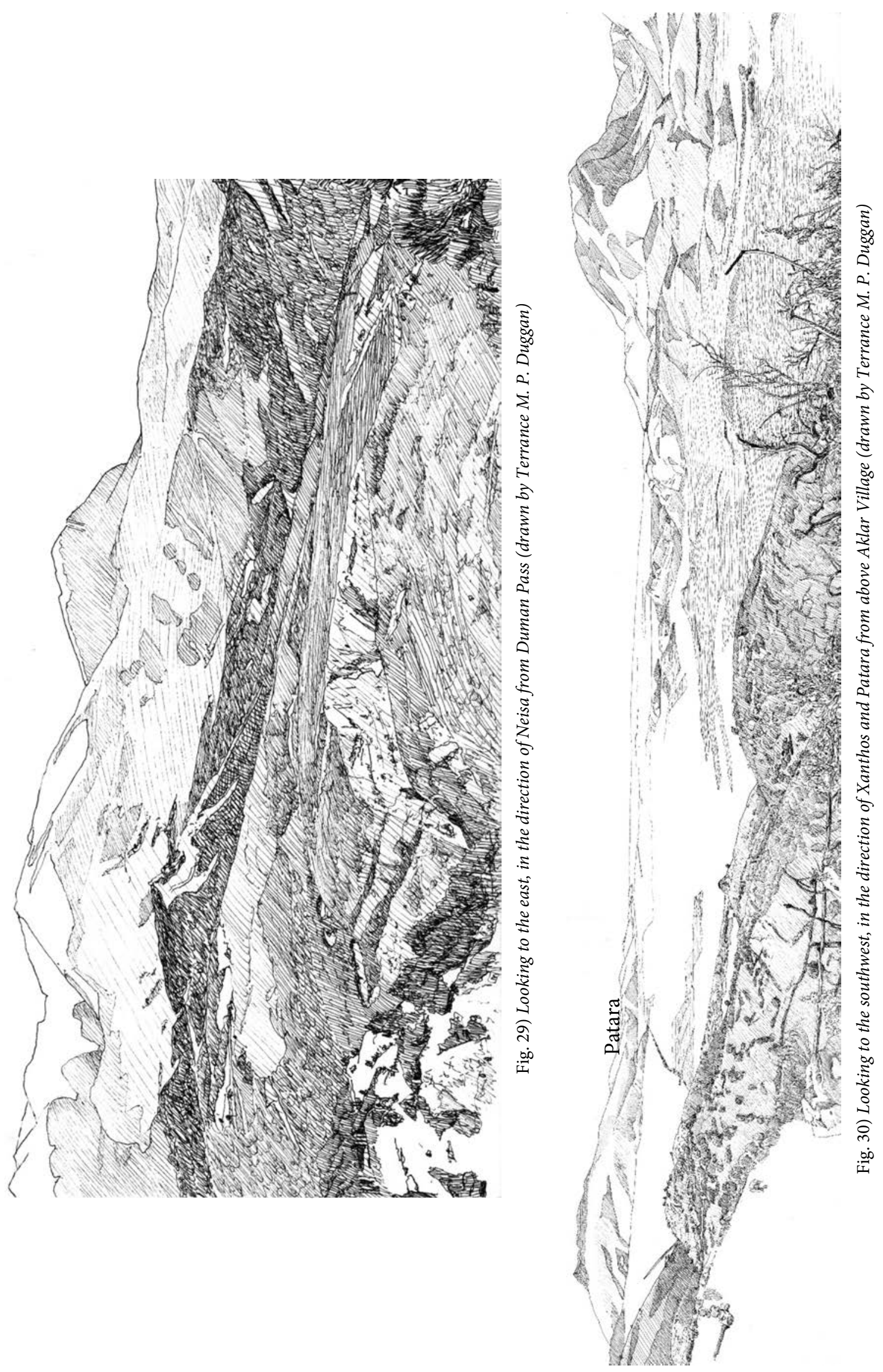